\title{
Kuidas võõras muutub omaks: kaks taime eesti rahvameditsiinis ${ }^{1}$
}

\begin{abstract}
Renata Sõukand
Teesid: Kummelit propageeriti eestikeelses kirjasõnas juba alates 18. sajandi lõpust, arnika nimetus ilmus sinna alles 19. sajandi keskpaiku. Jakob Hurda taimravi puudutavate tekstide kogu põhjal on arnika (kohaliku taimena) esindatud kummelist arvukamalt. Kuidas jõudsid need taimed eesti rahvameditsiini? Nimetus kummel (saksa k Camilla) omistati mõlemale. Alles siis, kui taimed muutusid Eesti looduses tavalisteks, hakkas pärimus nende kasutamise kohta laiemalt levima. Arnika nime prototüüp aga levis vaevaliselt kultuurtaimenagi, kuid laenas oma nime mitmele kohalikule taimele, edestades niiviisi kummelit ja kinnistudes kultuuriruumis. Mõlemad taimed muutusid ajapikku "omaks", säilitades seejuures "võõrast" hõngust tekkinud erilise, lisajõudu lubava tähenduse.
\end{abstract}

Märksõnad: arnika, eesti rahvameditsiin, kummel, oma ja võõras, taimravi

19. sajandist alates tutvustatakse ja soovitatakse populaarses eestikeelses tervishoiualases kirjanduses kohalike ravivahendite kõrval ka ravimeid ja raviviise, mis silmanähtavalt pärinevad mõnest teisest kultuuri- või looduskeskkonnast. Seda tendentsi peegeldab ka Eesti looduses puuduvate või alles hiljuti tuntuks saanud taimede nimetuste esinemine eesti rahvameditsiini taimravi andmebaasi HERBA (http://www.folklore.ee/herba) sisestatud 19. sajandil kogutud rahvameditsiinialastes pärimustekstides. Teiste selgelt võõrapärase päritoluga taimenimetuste hulgas kohtab seal kahte taime: arnika (nimekujuga arnik, arnikas, arnikid jne) ja kummel (kamilla, kammel, kommel jne).

Kuidas sattusid need taimed eesti rahvameditsiinis tuntud ravimtaimede hulka? Kas nad on ka füüsiliselt esindatud Eesti loodusruumis? Vaatlen kahe algselt võõrasse loodusruumi kuulunud taime esinemist ja tõenäolise sattumise teid eesti rahvameditsiini ning püüan nende varal selgitada "võõra" "omaks" transformeerumise mehhanisme. 


\section{Kummel ja arnika pärimuses ja 19. sajandi kirjasõnas}

Esmakordselt nimetab mägiarnikat kirjalikes allikates baltisaksa publitsist, kodu-uurija ja keelemees August Wilhelm Hupel (1737-1819) 1777. aastal, kusjuures mägiarnika esineb tal looduslike taimede loetelus (Hupel 1777: 519). Ka teekummel oli A. W. Hupeli andmetel selleks ajaks looduslikult levinud (Hupel 1777: 493). Lõhnavat kummelit nimetab esmakordselt Saksamaal sündinud, Göttingeni Ülikoolis teoloogiat ja loodusteadust õppinud ning hiljem Saaremaal elanud ja seal eesti keele selgeks õppinud arst ja vaimulik Johann Wilhelm Ludwig von Luce (1750-1842) oma entsüklopeedilises teoses Topographische Nachrichten von der Insel Oesel, in medicinischer und ökonomischer Hinsicht, mis kirjeldab Saaremaa floorat (Luce 1823: 282).

Juba esimene eesti etnobotaanik Gustav Vilbaste tõdes, et mägiarnika, mida looduses ei esine, on oma nime andnud kohalikele taimedele:

Arnika montana ei kasva Eestis metsikult, sest ta põhjapiir on Lõuna-Kuramaa (Kurzemes). Eestis ei arene arnikas hästi isegi mitte kultuurides. Sellest hoolimata kasvavat meie metsades rahva teadmist mööda sagedasti arnikat, mida kasutatakse tihti kodusel ravimisel tõelise arnika asemel ning turustatakse samuti rohuturul. Rahva keskel peetakse suurt osa kollaseid korvõielisi arnikaks, mis tegelikult on liigid perekondadest Leontodon, Hieracium, Crepis, Solidago (Vilbaste 1993: 174).

Noorema põlvkonna botaaniku Toomas Kuke koostatud Eesti taimestiku andmetel kasvab mägiarnika Eestis harva kultuuris; kunagine looduslik esinemine pole tõendatud (olla kasvanud Emajõe kallastel) (Kukk 1999: 99).

G. Vilbaste andmetel jõudis teekummel Eestisse enne 17. sajandit, lõhnav kummel ilmselt 19. sajandil (1993: 422-423). Praeguseks on lõhnav kummel kohalikus looduses hästi kohanenud, kasvab massiliselt käidavates kohtades ja seetõttu tuntakse seda taime hästi. Seda peetakse niivõrd omaks, et naljalt ei teki kellelgi mõtet, et tegu on tulnuktaimega. Ka teekummel on praeguseks loodusesse levinud, kuid seda ei kasva nii massiliselt kui lõhnavat kummelit - pigem on tegu kultuurtaimega (Kukk 1999: 102).

Niisiis esindavad kahest valitud taimenimetusest 19. sajandi lõpuks kohalikus looduses ühte nimetust (kummel) kaks taimeliiki (lõhnav kummel ja teekummel), samas kui teise nimetuse prototüüp (arnika) kasvab vaid kulti- 


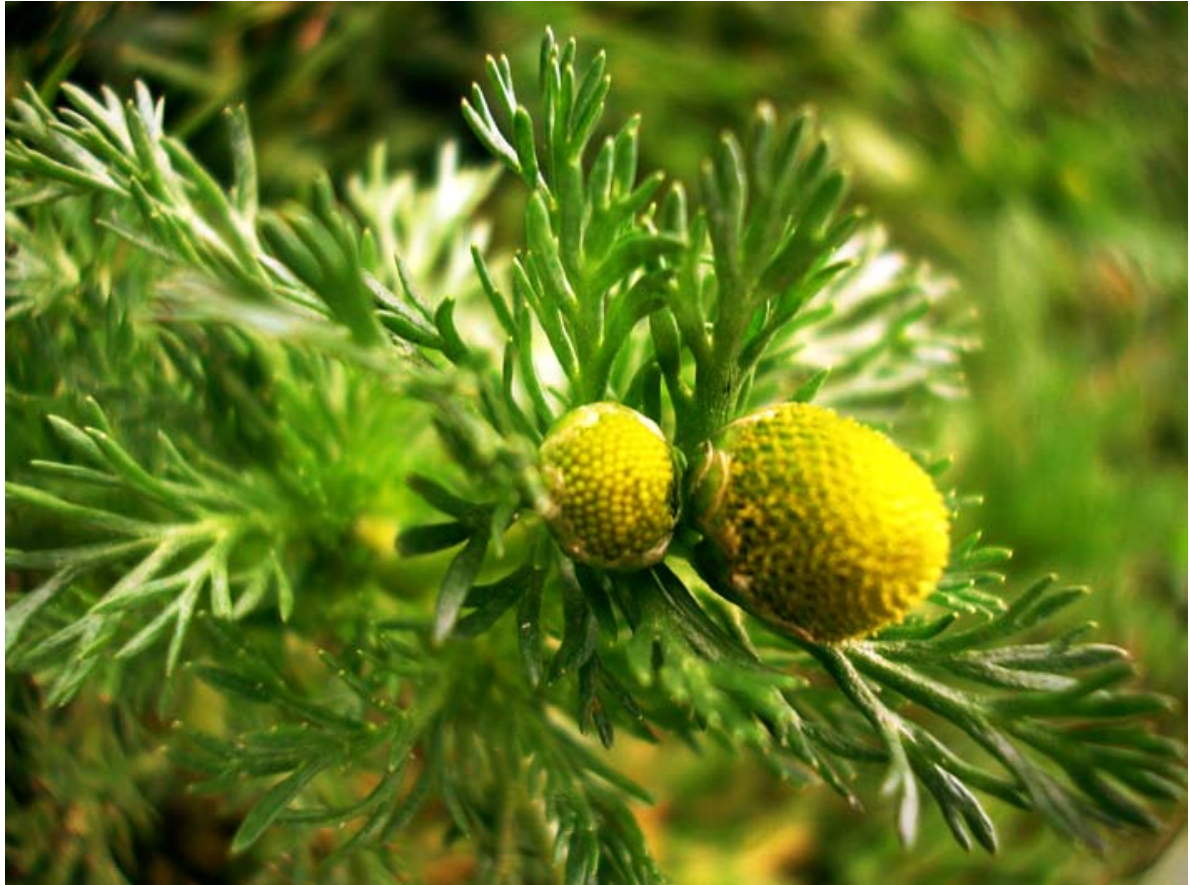

Foto 1. Lõhnav kummel. Foto Renata Sõukand 2004.

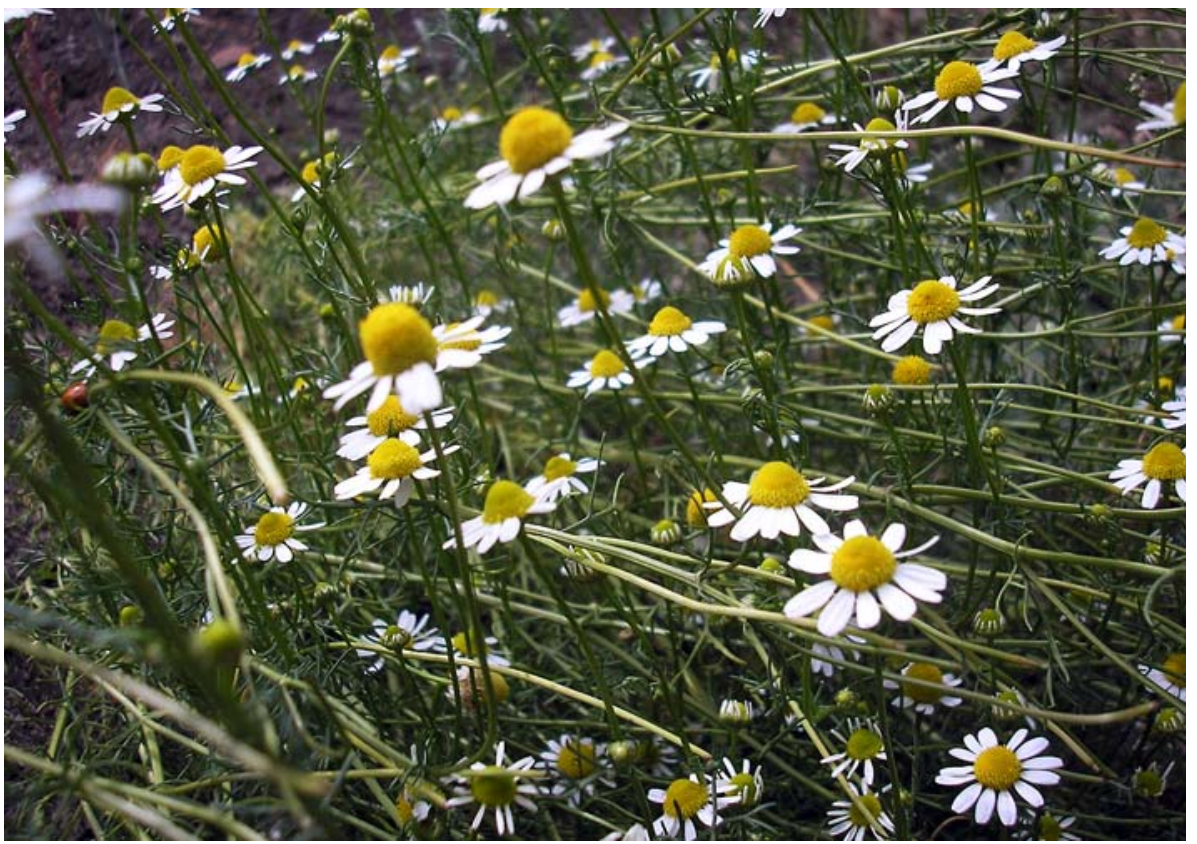

Foto 2. Teekummel. Foto Renata Sõukand 2006. 
veerituna, kuid on tõenäoliselt andnud oma nime erinevatele kohalikele taimedele. Järgnevalt vaatlen, kuidas need nimetused on esitatud kirjasõnas ja pärimuses. Et pärast 1900. aastat ilmunud taimravi tutvustava kirjanduse hulk on aukartustäratavalt suur, piirdun vaid enne seda ilmunud kalendri- ja populaarse tervishoiukirjanduse analüüsiga. Paralleelselt vaatlen folkloristi ja keeleteadlase Jakob Hurda (1839-1907) rahvaluulekogus (1888-1906) sisalduvaid arnikat ja kummelit puudutavaid tekste, et hinnata kirjanduse potentsiaalset mõju pärimusele.

\section{Lühhike öppetus...}

Esimene teadaolev eestikeelne meditsiinialane kirjalik allikas, milles kummelit nimetatakse, on Põltsamaa arsti ja apteekri Peter Ernst Wilde (17321785) saksa keeles kirjutatud ja August Wilhelm Hupeli eesti keelde tõlgitud Lühhike öppetus, mis sees monned head rohhud täeda antakse, ${ }^{2}$ mis ilmus aastatel 1766-1767 neljakümne ühe õhukese vihikuna, kokku 164 lehekülge. P. E. Wilde nimetab saksakannapersed ${ }^{3}$ kogu ajakirja väljaandmise jooksul seitsmel korral (18., 22., 25. ja 40. osas). Kõigepealt soovitab ta kasutada neid ülespaistetuse raviks rinnatõve ja köha korral, lisaks Vildri pu kasudele (Wilde 1976: 65). Hiljem lisas ta näidustuste hulka ka paistetuse, mille puhul soovitab kummelit kasutada pehmendava ja mäda väljutava vahendina. Salvi valmistamisel olid vajalikud veel hullo koera rohhud ja linaseemneõli, ka kasutati kummelikeedupiimaga täidetud sooja kotti paistetuse ravimiseks lastel (Wilde 1976: 87-88). Nimetuse saksa kanapersed juurde tuleb P. E. Wilde tagasi veel 25. peatükis, toonitades, et talupoeg küll tunneb taime, kuid kasutab seda valel otstarbel:

Saksa kanna persed, sinna tunned kül sedda rohto, agga se suur väggi mis selle rohho sees, on sul teädmatta; sinna värvid agga nende kallaste õisedega. Külmas tõbbes on need õied vägga head, keigeennamiste neile kelle ihho pissut nõrk on [---] (Wilde 1976: 95).

Ka soovitab ta kasutada taime sünnitusabis (Wilde 1976: 154). Nii antakse eestlastele juba esimeses arstiteaduslikus ajakirjas mitmeid soovitusi kummeli kasutamise kohta, eeldades, et talurahvas taime tunneb ja ka õigel otstarbel kasutama hakkab. 


\section{Kalendrilisad}

Kuigi meditsiiniliste nõuannete ilmutamine kalendrilisades sai alguse juba 1792. aastal, ${ }^{4}$ mainitakse kummelit kalendrites esmakordselt alles Tallinnas Minuthi kirjadega ilmunud 1804. aasta Eesti-Ma-Rahva Kalendris. Peatükis, mis kirjeldab nii poodu kui kägistatu abistamist, nimetatakse kummelit nimega kanaperse [---] muude kange haisoga rohtude seas, mille keeduvett tuli kannatanu ihule panna või pidi teda selle sees vannitama. Siin on kummelit soovitatud just vänge iseloomuliku lõhna, mitte muude raviomaduste pärast (EMRK 1803).

Ajaliselt järgmine kalender, 1856. aastal ilmunud Eesti rahva Kalender se 1857 aasta peale pärrast J. Kristusse sündimist, Trükkitud Ria linnas Mülleri trükki kojas, annab põhjaliku ülevaate nii teekummeli (nimetatuna kanna persed ja ubbina hain) lehtede kui õisikute kasutamisest. Potentsiaalselt ravitavate haiguste nimekiri on pikk, sisaldades külmetushaigusi, seede(elundkonna)häireid, naistehaigusi ning ka välispidiselt ravitavaid paiseid ja nahahaigusi.

Kanna persed, ehk übbina hain (Matricaria Chamomilla) kasvavad kövva tühjaksläinud kohtade peal, teede ja honede liggi; nad öitsevad Juni ja Juli kuul. Prukimisse tarvis korristakse kanna-persede lehta, neil on joudu andja, ärrataja, mao kinnitaja, riete peälse aiaja, krampi ja külma-többe vastane luggu. Kanna-persed on üks neist keige tullusamaist ja keigile tutvaist taimist, mis prugitakse. Alv rahvas prugivad kassuga kanna-persede lehta vahhetava külma-többes, neid kui pulvrid $1 / 2$ solotniku ja ennam ühhe korraga sisse andes. Korrad, kunnas kanna-persede öied heaste aitavad, on need: sone soe-többi, kui vaja on köhhu liikmette teggemist ärratada; emma vigga naestel, isseärranis mao sone-vallu naeste asjade ajal ja pärrast mahhasamist, peru kogguminne, mis solikatte seadmisse nödrussest tulli, okse löppetusseks, mis okse rohhuga tehtud sai, ja kui üks väljaspiddine viis, pehmeks teggia padjakeste näul mitme paisude, vasto töukamiste, helletingu ümberpannemisseks ja nt. klistrid kanna-persede üllestömbamissest teggevad heaste köhhu pussus ja kokkokiskumisses. Ühhe naela üllestömbamisse valmistamisse tarvis on 3 solotniku kuivaid lehta (ERK 1856).

Järgmise aasta Eesti rahva Kalender se 1858 aasta peale pärrast J. Kristusse sündimist. Trükkitud Pildide ja ramatu trükja Hartungi kojas, nimetab kam- 
meli teevee kasutamist vanade või nõrkade inimeste ravimisel pärast kanget hopi ehk siis toonikuna (ERK 1857).

1880. aasta Pärnu Eesti-rahva Kalendris ehk Täht-raamatus soovitatakse kummelit kasutada esiteks viinaleotisena pistehaava peale ja siis piimakeedisena muljutud haava peale. Ka kirjeldatakse selles kalendris naba paigast ära olemist, mis kalendri autori arvates ei ole muud kui kõhu valu, mis töstmise läbi sündinud ning selle ravimisel on esimeseks valikuks kummeliõite tõmmis, samuti soovitatakse teiste hä̈ haisuga rohtude hulgas kummelikotike soojalt kõhule panna. Lisaks soovitatakse arnika rohtu õllega keeta ja haigele juua anda (PERK 1879).

Samal aastal teise kirjastuse poolt välja antud Pärnu Kalender ehk Tähtraamat 1880 aasta pääle, pärast Jeesuse Kristuse sündimist nimetab arnikat marraskil naha ravimina, kusjuures kalendris seisab, et see teave on võetud 1880 a. Vene Kalendri seest (PK 1879). Ilmselgelt ei ole siin mõeldud kohalikke arnikaid.

1887. aasta Rahva Täht-raamat (Adressi kalender) soovitab kasutada mädapaisete raviks kummelikompressi kliidega ja kurguhaiguste puhul hingata sisse kummeliauru, toonitades, et nõuanded on mõeldud kergemate haigusvormide puhuks (RTR 1886).

Sama aasta Eesti rahva Kasuline Kalender (trükitud Tartus Laakmanni trükikojas) nimetab kummelit siniseks kanalilleks ja soovitab hambavalu korral sinist kanalille tinktuuri (Blaue Camillen-tinktur) veega segatult iga veerand tunni järele natuke suhu võtta. Viide sinisele värvusele aitab tuvastada teekummeli. Viimane sisaldab matritsiini, millest eeterliku õli destilleerimisel tekkiv hamasuleen põhjustabki sinist värvust. Samas soovitab ta juua ka kanalille theed (Chamillenthee). Saksakeelsete nimede kasutamine ja kiniini mainimine kalendris viitab tõlkeallikatele (ERKK 1886).

1896. aasta $S$. W. Haynbergi värvi-ja vürtsikaupluse Kalender nimetab arnikat tilgarohtude hulgas koos baldriani, galgani, entsiani, aloe ja paljude teistega ning kirjeldab tilkade valmistamist baldriani näitel (SWHKK 1895).

1899. aastal Tartus Eesti Üliõpilaste Seltsi väljaandel ilmunud Sirvilauad. Eesti rahva Tähtraamat räägib arstirohtudest ja nende tarvitamisest juba kriitilisemalt. Seal nimetatakse arnikat kangete rohtude hulgas, mida peab tilkhaaval võtma ja mis lugejale väga tuttavad on igapäevase tarvituse läbi. Ka kirjeldatakse selles kalendris Kusmitshi heinaks nimetatud rohtu, mille eest kaupmehed hingehinda küsivat.

Ajalehtede kuulutused kiidavad tema mõju igapidi taevasse. Nii lugu muidugi ei ole, aga natukene mõju on tall ommeti. Kui meie kodumaa rohtudega teda võrdleme, siis võiks Kusmitshi heina mõjuduse poolest 
veriheina-ja arnikatee vahele seada. Ennem võib aga veriheinale või arnikale tervekstegeva mõju poolest eesõigust anda. Ei ole siis kellelgi tarvis seda võerast kaupa, mis jaolt koguni kopitanud, kalli raha eest osta. Võib oma väljalt veriheina või arnika õisi korjata ja oma raha paremasse paika panna, kui petjate taskusse (SL 1898).

Selline sõnastus annab põhjust oletada, et arnika all peetakse silmas mõnd kohalikku taime, mis on sama tuntud nagu verihein.

Niisiis võib oletada, et trükisõna (Lühhike öpetus... kaasta arvatud) on mänginud kummeli populariseerimisel märkimisväärset rolli. Seevastu arnikat nimetatakse oluliste taimede hulgas alles 1880. aastal, kusjuures see jäetakse siiski apteegirohtude või lihtsalt võõramaise päritoluga taimede (v.a SERT 1898) nimistusse. Kusjuures kalendritest paistab silma asjaolu, et arnika toimed ei ole vajanud otsest tutvustust, mis eeldab vähemalt kirjutaja arvates selle mõningast tuntust rahva hulgas.

\section{Aimekirjandus}

Ka 1771. aastal ilmunud A. W. Hupeli tõlgitud raamatus Arsti raamat nende juhhatamisseks kes tahtvad többed ärraarvada ning parrandada nimetab Peter Ernst Wilde kummelit saksa kanaperseks ja soovitab seda kasutada mitmete haiguste vastu. Näiteks naistehaiguse puhul (emmaga vigga) koos linaseemnete ja humalaga, naisterahva minestamise puhul saksa kannapersete, raud rohu ja poio keedist (Wilde 1771: 49-50). Lapse rõugetest päästmiseks tuli teha jägmist:

[---] votta saksa kannapersed üks pool peo täis, valla üks pool toop pima peale, keeta sedda, kurna läbbi, valla kaks lussika täit ôlli jure, votta vähhem kui pool ning pumpa sedda lapsele taggant sisse (Wilde 1771: 96).

Ka sobisid saksa kanapersed laste oksendamise vastu, kuid neid tuli eelnevalt kuivatada. See võib viidata asjaolule, et talupojal võis kummel aias kasvada või oli tal võimalus seda mõisast hankida (Wilde 1771: 100).

Nicolaus von Hagemeisteri 1790. aastal ilmunud Lühhikene öpetus maarahvale, mis visi nendega peab ümberkäma, kes vees uppunud ja muu villetsusse sisse sanud, ehk äkkitselt surnud, et nemad ello jälle voiksid sada nimetab saksa kanna persedest (segus mündi, salvei ja melissiga) tehtud teed profülaktiliseks joogiks ja kooleraravimiks (Hagemeister 1790). 
Ka kaheksaleheküljelises brošüüris Oppetus kuitao ma-rahvas henda köttotöbbe eest peap hoidma ehk kui ta selle kimpu sisse om johtunu, temmast pea jälle voip avvitetus sada, mille sisu alapealkirja järgi oli tallomeeste häes üleskirjotu Marjenburgi Surest Herrast Baron Witinghowist, Lettikele päle ärratölkitu Marjenburghi Kerk-Herrast Rülist ja Tartomaa-kele päle ärratölkitu Tartolina üllemast Kerk Herrast Wanna Lenzist, nimetatakse ubbina haina vett koos linaseemneveega väga heaks kõhutõverohuks, kuid sellest paremad olevat Vietinghoff-Scheel väite kohaselt siiski mustikamarjad (VietinghoffScheel 1807: 7).

1816. aastal ilmus Tervise Kateksimusse Ramat, mis oli esmalt Saksa kele, Ma rahva heaks kirjotanud Johan Willem Luddi Ludse, arst ja kolide üllevaataja Kurresare linnas ehk Johann Ludwig von Luce, kes ka ise oli Saaremaal palju taimravialast pärimust kogunud. Raamatu oli tõlkinud Kusto Hinrik Schmidt. ${ }^{5}$ J. L. von Lucel olid laialdased botaanikaalased teadmised, ta publitseeris juba 1823. aastal Saaremaa floorat käsitleva teatmeteose, kus tutvustas mitutkümmet taime. Nende hulgas nimetas ta mitmel korral ka kommeli kasutamist järgmiste haigusseisundite raviks: üldise haigestumise ajal, kurgutõve, laste kõhupuhituse, venituse (nabba assemelt ärra), pistmise ja villitõve korral (Luce 1816: 79, 85, 86, 109).

1857. aastal kirjutas Laiusel sündinud, kuid hiljem Riia eesti Jakobi kiriku pastorina teeninud Otto August Jannau (1800-1865) oma raamatus MaRahva Koddo-Arst ehk lühhikenne juhhataja, kuida iggaüks mõistlik innimenne ommas maias ja perres, kui keegi haigeks saab, agga arsti ep olle sada, võib aidata ${ }^{6}$ kummelist (nimetades seda ka saksa kanaks ja saksa kanaperseks) terve peatüki ja soovitab seda kasutada kõhuhaiguste, paistetuse, naha- ja naistehaiguste vastu, kusjuures ta rõhutab selle erilist head mõju just viimase puhul.

Saksa kana. Saksa kanapersed ehk kummelid. Viljakandja maas, hoonete ligi, rohuaedades, olgu et iseenesest, ehk olgu külvatud kasvamas. Teda pruugitakse mitmes haiguses:

1) $K \tilde{o} h$ u $t \tilde{o} b$ e s, näpistamises, krambis juuakse temast keedetud vet. Paksu, mis järele jääb, pannkase nartsu wahel soojalt mau kohta. -2) Piimaga keedetud audutakse paksuga kõva $p$ a $i$ s t e $t u s i$, nii kaua kui pehmeks saavad. -3) Kuivalt pannkase teda linase kotikesega helitingu peale. -4) Kui n a e s t e a s j a d ja kuu aegsed ep ole omas korras ning ärajäänud ehk peaksid tulema, ei ole paremat, kui kummeli vet soojalt juua, 3 kord pääwas tassi täie, ennast soojas pidada sängis ning külmetamise eest hoida (Jannau 1870: 40-41). 
Veel nimetab ta kummelit raudreiarohu peatükis, kus soovitab seda kasutada koos raudreiarohuga paistetanud haavade peale panemiseks (Jannau 1870: 38).

O. A. Jannau toob ka eraldi välja taime nimega kana persed, mis on:

Saksa kanaperse sarnane, aga suurem ja pahast haisust. Maust on ta kiba ja mõru, kasvab kuiva kesamaas ja välade peal (Jannau 1870: 17).

Seda anti veistele seedimise parandamiseks. Ilmselt on siin tegu mõne kohaliku kummelisarnase taimega, näiteks hariliku kesalillega (Matricaria perforata), mida rahvas on hiljem kummeliks kutsunud ja mida ka paljud autorid kanaperse erinevate variatsioonidena on nimetanud (Vilbaste 1993: 633).

Üks O. A. Jannau raamatu peatükk räägib arnikast:

Naeste punad ehk olankad. Arnika. Tee ääres, lehepuu metsades, kuivas kohtades ja aedade ääres, kus ta Jaani pääva aeal õitseb. Vars on puine, sile, peaaegu kaheterane, sirge, 1 ja 11/2 jalga pik. Lehed on tõmbilised, siledad, mitme läbipaistva tipsokestega. Need on täis õli ning purpuri punast sahvti. Lilled on kollased. - Lusika täie rohu peale vala rohket korteri jau keeva vet, seda kata kinni ning lase tük aega seista. Seda vet võta siis iga kahe tunni pärast kopso tõbes, ehk kui inimene tõstmise läbi viga saanud. Värske haavadele, muljumises, põletamises ei või paremat abirohtu leida, kui selle rohu sahvti, parem veel, kui seda joodava viinaga võimalik segada, - peale panna (Jannau 1857: 32).

Selles tekstis on kirjeldatud lihtnaistepuna (Hypericum perforatum), nagu selgub ka G. Vilbaste Eesti taimenimetustest (1993: 366). Taime on siiski nimetatud eeskätt naistepunaks, nimetus arnika on teisejärguline. Soovitusedki (kopso tõbes, kui inimene tõstmise läbi viga on saanud ja haavadele (kõige parem viinaleotisena)) on seostatavad nii lihtnaistepuna kui ka arnika hilisema rahvapärase kasutustega (HERBA).

Õpetaja ja preester Johannes Jaanus (1861-1941) nimetab 1893. aastal ilmunud raamatus Rahva tohter. Arstlikud õpetused, kudas inimesed endid haiguste eest võiksivad hoida ja tõbesid parandada kummeliteed ainsa luupainajaravimi (Jaanus 1893: 29) ja esimese valikuna kõrisõlmepõletiku ravimisel (Jaanus 1893: 17). Kange kõhuvalu puhul olla kummelitee aga teiseks valikuks linaseemnete kõrval (Jaanus 1893: 48). 
Tõlkeraamatus Maja tohter. Juhatus, kudas arsti-abi puudusel igasugu haigusi ise võib kergitada ja parandada, ${ }^{7}$ mis ilmus eesti keeles esmakordselt 1891. aastal, soovitatakse kummelikompressi nurganaiste uriinipeetuse korral, samuti ka putukamürgistusega kaasneva oksendamise korral. Tema raamatus nimetatakse kummelit kamela, mis ilmselt tuleneb saksakeelsest Camillast (Maja tohter 1891: 24)

Lisaks O. A. Jannau kuues trükis ilmunud teosele mainitakse arnikat sakslasest katoliku preestri ja vesiravi rajaja Sebastjan Kneippi (1821-1897) tõlkeraamatus (tõlkija Mats Tõnisson) Uus tohter. Õpetused, kuidas inimesed igasugu haiguseid aurutamisega, vee vannitustega, peale valamistega, märja mähitustega jne kui ka oma korjatud rohtudega arstida võivad. ${ }^{8}$ Koos vesiravi tutvustusega annab autor ka põhjaliku "arstirohtude" nimekirja koos taimekirjelduste ja nende kasutamise selgitustega.

Nimetus arnika esineb siin kõrvuti ladinakeelse nimetusega, kuid see kirjeldus ei vasta kuidagi Arnica montana kirjeldusele:

\section{Arnika (Arnika montana)}

Arnika ehk naistepuna kasvab kuivas kohtas, lehtpuu metsades, teede ääres ja õitseb Jaani päeva ajal. Tema vars on puine, sile, peaaegu kahe terane, 1-11/2 jalga pikk, aga sirge; lehed on tömbilised, siledad, mitme läbipaistva tipsukesega; õied on kollased.

Arnika on terves maailmas mõnusa arstirohuna kuulus.

Arnika=tinktur on nii üleüldiselt tuttav ja haavade pesemiseks, pealepanekuteks (kompressideks) j.n.e. nõnda üleüldiselt pruukis, et ma mitte tarvis ei arva olevat selle üle pikemalt kirjutada.

Arnika tinkturi müitakse igast apteegist ja kaunis odavalt. Igaüks võib teda aga ka hõlpsaste ise valmistada. Õied saavad Juuni kuu lõpul ja Juuli kuu alus/pag 113/tusel korjatud ja viina ehk piirituse sisse pandud. Juba umbes kolme päeva pärast võib valmis tinkturi pruugitusele võtta (Kneipp 1895: 112-113).

Selles tekstis kirjeldatakse tõenäoliselt hoopis lihtnaistepuna (Hypericum perforatum). Raamatus (lk 118) nimetatakse lihtnaistepuna aga jaani punaks, kuigi kirjeldatakse pigem kandilist naistepuna (H. maculatum). Mõlemat liiki kasvab Eestis üsna arvukalt ja nende vahel vahet teha on harjumatu pilguga väga raske. Kandilist naistepuna eristab just kandiline vars, samas kui lihtnaistepuna vars on kahe soonega. Kuigi tegu on tõlkekirjandusega, eeldatakse automaatselt ka eesti lugejalt arnika tundmist ja taime kasvamist käeulatuses. On tõenäoline, et tõlkija on püüdnud materjali kohalikule lugejale mõistetavamaks kohandada ja lisanud taimekirjelduse, toetudes Otto August Jannau tekstile. Kahe teksti taimekirjeldus on teatud 


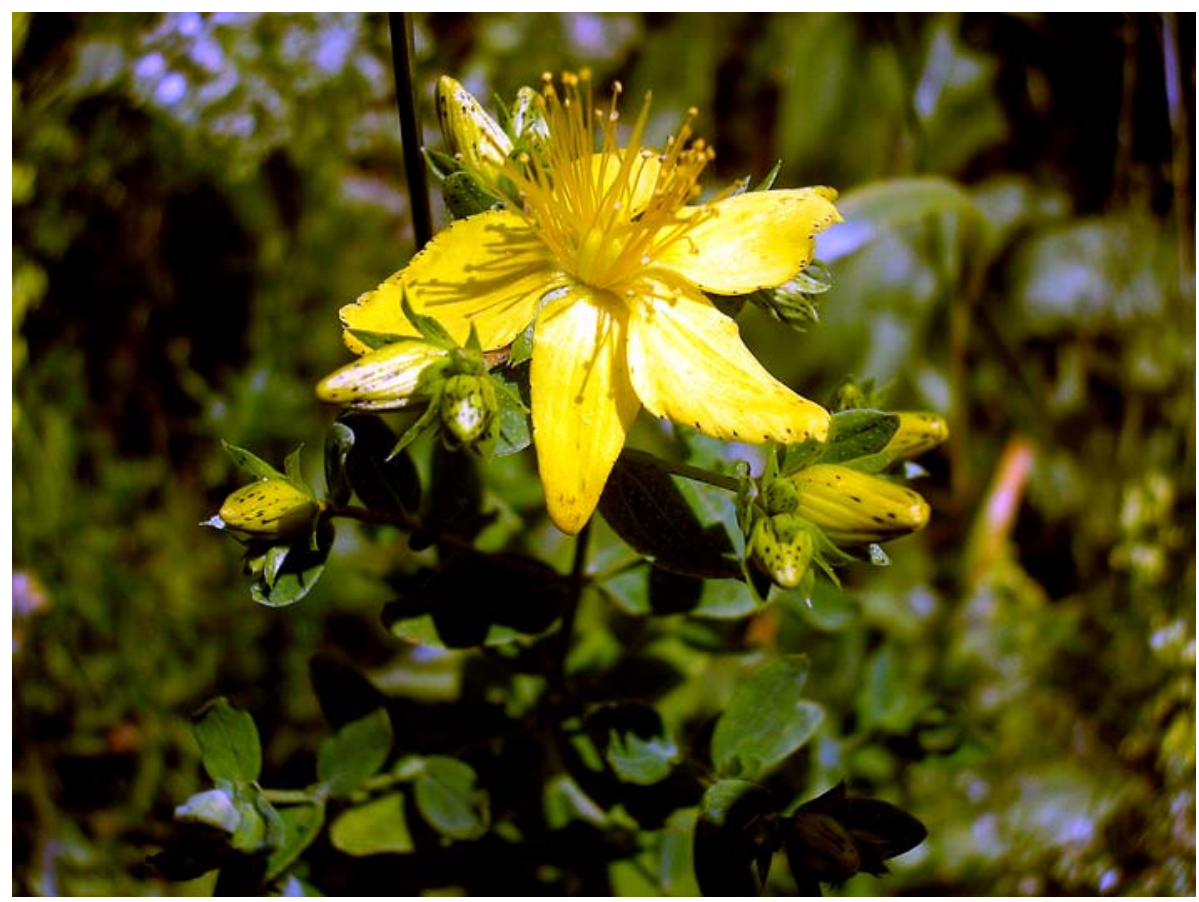

Foto 3. Kandiline naistepuna. Foto Renata Sõukand 2006.

ulatuses sõna-sõnalt identne (vrd Jannau 1870: 29). Ka tõlketeksti ja S. Kneippi raamatu 49. väljaande (Kneipp 1894) võrdlemisel selgus, et eestikeelses versioonis on mitmele taimele lisatud kasvukoht ja taimekirjeldus, nagu ülaltoodud teksti esimeses lõigus, kusjuures tõlkijal on jäänud märkamata, et õitsemisaega korratakse teksti lõpus. Ka esineb arnikast valmistatud tinktuur pisukese koduapteegi sisus, kuid siia ei ole lisatud ladinakeelset vastet (Kneipp 1895: 144).

Ka S. Kneippi raamatus ei puudu kummelid, seekord koos ladinakeelse nimetusega Matricaria chamomilla. Kummeliteed soovitatakse pruukida külmetuse, ägeda kõhuvalu, krampide jne raviks. Tõlkija on tõenäoliselt omalt poolt lisanud teksti algusesse, et taim kasvab rohtaedas, muruplatsil ja vilja kandjas maas, hea lõhnaga, ning ta lõpetab teksti sulgudes oleva lausega: Kes ise pole aega noppida saanud, see võib neid ka apteegist ehk rohupoodidest osta (Kneipp 1895: 128, vrd Kneipp 1894).

Kuigi käsitletud kirjanduse nimekiri pole lõplik (autor on läbi töötanud vaid osa uuritaval ajajärgul ilmunud trükisõnast), võib siiski öelda, et kirjandus populariseeris just kummelit kui väga laia toimespektriga ravivahendit. Suure hulga kummeli kasutust kirjeldavate tekstide kõrval esineb vaid 
kaks arnikast kõnelevat kirjutist (ja needki kirjeldavad tegelikult hoopis lihtnaistepuna). Järelikult ei saanud ka tolle aja kirjandus anda olulist tõuget arnikaks nimetatavate kohalike taimede ilmumisele rahvameditsiini. Sellegipoolest võisid just need kaks teksti, mis vihjavad arnika nimetust kandva taime kasvamisele Eestis, anda tõuke arnikaks nimetatavate kohalike taimede ilmumisele rahvameditsiini.

\section{Pärimus}

Jakob Hurda ravimtaimetekstide koguga tutvudes avaneb hoopis teistsugune pilt: pärimuses on arnika hoopis olulisem. Vaid kaks viiest J. Hurda kogus leiduvast arnikat käsitlevast tekstist viitavad sellele kui ilmselt mittekohalikule taimele. Väike-Maarja kihelkonnast pärit 19-aastase Karl Voldemar Lurichi kirjutatud tekst samastab kohaliku taime kasutamist arnika kasutamisega:

Ämmatuss saab tarvitud nagu arnika (H II 12, 170 (40) < VäikeMaarja khk - Karl Voldemar Lurich (1890)).

Seejuures on oluline, et siin ei nimeta ämmatussi, mis on tõenäoliselt Eestis kasvav murumuna, kasutamise otstarvet. See viitab tõigale, et arnika kasutamine pidi olema teada-tuntud vähemalt selle kirjasaatja kogukonnas. Huvitav on siiski täheldada, et kõik teised selles saadetises nimetatud taimed (põdrasammal, emanõges, koirohi jne) kuuluvad vaieldamatult kohalike ravimtaimede hulka (H II 12, 168-1719), kuid samas nimetab K. V. Lurich ka safranit (H II 12, 169 (31)) ja salpeetrit (H II 12, 169 (32)), mis kindlasti eeldab teatud meditsiinikirjanduse lugemust või vähemalt apteegirohtude tundmist.

Teine tekst, mille on kirja pannud Märjamaa kihelkonnast pärit Eestimaa kubermanguvalitsuse ametnik Adolf Ferdinand Bernstein, ei võimalda täpselt määrata taime päritolu, sest ôllega võis keeta ka apteegist saadud mägiarnikaõisi. Kahtlust, et need ei ole kohalikud taimed, suurendab asjaolu, et ta soovitab nimetatud ravimeid kasutada juhul, kui kodused vahendid üks supilusikatäis tuhka või peeneksõerutud telliskivi, kivisütt, rauasitta või -puru veega ehk viinaga (H II 16, 558 (3)) ei aita. Ka tekstis nimetatud liikvere-eli ja türgipipra viin on suure tõenäosusega apteegist pärit.

[Kõhuvalu puhul.] Kui see pole aitanud, olla teisa rohtusid katsutud, nagu: arnikad keeta ôllega ehk liikvere-eli lusikatäis veega ehk türgi- 
pipra viina ehk venitamise eli (H II 16, 560 (7) < Tallinn < Märjamaa khk -Adolf Ferdinand Bernstein (1890)).

Ülejäänud kolm Jakob Hurda kogus leiduvat arnikat nimetavat teksti viitavad selgesõnaliselt kohalike taimede kasutamisele.

Saatmise hetkel Suhhumis elanud, kuid Jüri kihelkonnast pärit Johan Pihlakase 1889. aastal lähetatud tekstist võib välja lugeda, et üheaegselt oli olemas koguni mitu erinevat arnikat. Ta nimetab valgeid ja kollaseid metsarnikaid, mis jätab ruumi oletusele, et on olemas ka mittemetsarnikad. Arnikate värvus viitab ilmselgelt nende õite värvusele ja kui valge metsarnika puhul saab oletada, et tegelikult on kirjeldatud angervaksa (Filipendula ulmaria) (Vilbaste 1993: 317-318), siis kollaste metsarnikate puhul tuleb valik teha mitmekümne taime hulgast.

Kui laps vällä on sõnatust, siis on tarvis ninda ohutada. Korja (otsi) 12 sugu rohtusi: punaheinu, lehmäsõrarohtusi, kaituserohtusi, jaanilillesi, reinvarresi, sookaisläid, kõrvekollast, raudrohtusi, koirohtusi, valgeid metsarnikaid, kollaseid metsarnikaid ja ubalehti. Igaüht võta kolme näpuga ja keida ummuses vällä, ninda kaua, kui kaks jägu vällä saab keinust ja üks järele jääb, ja pane pudelisse. Saab ta jahtunust, pane viinaklaasi vie ehk piima hulka 6-9-12 tilka, kui suur laps on, ja anna sisse. Muist rohtusi, midä keitmata jäi, kuivata vällä, pühi tuapühkeid hulka ja pane ukse all põlema. Siis võta laps alasti, kisu luud laiäli ja lase lapsele läbi luua suitsu, kuni laps läkästab. Millal ninda teed, igä kord avitab. (Lüganuse kihelkonnast saadud) (H II 33, 838 (7) < Suhhum-Kalee < Jüri khk, Rae v, Kautjala k - Johan Pihlakas (1889)).

Viljandist pärit seltsitegelane ja kirjamees Anton Suurkask, kes kogus pärimust mitmelt poolt üle Eesti, oli Jakob Hurda üks suurkorrespondentidest. Tema tekstis on loetletud arnikaõied ja kummeliõied koos kohalike taimedega talurahva seas teeks pruugitavate seas, kusjuures arnikal nimetab ta ka kitsamat kasutusviisi - seestvalu vastu (see on samastatav venitusega). ${ }^{9}$ Siingi tekib väike kahtlus taimede päritolu suhtes: nimetamise viisi järgi (arnikaõied, kummeliõied) võib taimi pidada apteegist pärinevateks (vrd Wallner 1929: 9, 57), kuid teksti lõpuosas sisalduv taimede kuivatamise õpetus viitab otseselt talupoja käeulatuses kasvavatele taimedele. Seega võib ka selle teksti põhjal oletada, et nii arnikaks kui ka kummeliks nimetatu pidid olema kohalikud taimed ja kõnealused nimetused olid vähemalt selle kirjasaatja silmis tavapärased taimenimed. 
Taimed, mida talurahvas teeks pruugivad

1. Maasikalehed,-õied ja-marjad; lehed tulevad siis ära korjata, kui nad alles noored ja vaigused on. 2. Viinalille õienupud. 3. Härjapea ehk koorelille õienupud. 4. Pihlaka õienupud. 5. Veriheina õienupud-iseäranis veretõbede vastu. 6. Vahrakamarjad ja -varred, mis talvel tulevad lõigata. 7. Arnikaõied - seestvalu vasta. 8. Kummeliõied. 9. Valge ja punase ristikheina õied. 10. Mustasõstremarjad. 11. Mündilehed. 12. Valmissaanud köömned. 13. Mustad kadakamarjad. 14. Mustasõstrelehed, mis kevadel, kui nad alles noored ja vaigutsed on, ära tulevad korjata.

Kõiki neid teesid tuleb kas ulu all ehk mõne muu sarnase koha pääl tuule käes esiteks kuivatada, kuhu mitte päev pääle ei paista. Päeva päälepaistmise läbi saavad nad tervisele kahjulikuks. Pääle tuule käes kuivatamise tulevad nad ahjus, mis mitte liiga palav ei tohi olla, vaid sarnane, kui leivad on ahjust välja võetud, veel üle kuivatada (H I 9, 40 (12) - Anton Suurkask (1897)).

Ka kooliõpetaja August Tõnuristi tekst aastast 1889 nimetab arnika kasutamist venitamise vastu ja taime eelneva kuivatamise soovitus viitab kohalikule taimele.

Venitamise vastu on hea arnik, mis teest keidetasse, aga enne kuivatasse (H II 7, 883 (2) < Jõhvi khk, Edise v, Vasavere k-August Tõnurist (Tõnorist) (1889)).

Vaatamata sellele, et hilisemas eesti rahvameditsiinis on kummel üks populaarsemaid ravimtaimi, nimetatakse Jakob Hurda kogus kummelit vaid kahel ja uppinhaina (lõhnav kummel) ühel korral. Esimesel korral mainitakse seda ülaltoodud Anton Suurkase tekstis (H I 9, 40 (12)), kus soovitatakse kummeliõisi tee tegemiseks. Ainult õite nimetamine võib aga jällegi viidata kummeli apteegipäritolule (kuigi kogu kontekst lubab oletada vastupidist), sest üldjuhul müüdi apteegis just üksnes kummeliõisikuid. Teisel korral esineb kummel Gustav Seene (kogumise ajal meditsiiniüliõpilane) ja Peter Sauli (õigusteaduste üliõpilane) 1890. aastal kogutud saadetises, kus on kirjas ka kasutamise näidustused. Oluline on seejuures, et samas tekstis nimetavad kirjasaatjad veel ingverit (ingverituhka), mis võib muidugi olla ka võõra taime (ingver) kohalik teisend. ${ }^{10}$

Kummelitee veega tuleb silmi peseda, kui silmad vett jooksevad; kui karvad silma seespool ette tulevad, nopitakse nad ära, ja peeneks hõerutud suhkurt, mille juure üks väike osa ingverituhka juure lisa- 
takse, puhatakse sisse (H II 6, 310 (II) < Hiiumaa - Gustav Seen ja Peter Saul (1890)).

1880. aastal sündinud Gustav Loodus Kanepi kihelkonnast nimetab uppinahainateed viimase valikuna vahendiks rinnavalu vastu. Selleks ajaks (19. sajandi lõpp) oli lõhnav kummel ilmselt mingil määral looduses levinud taim ja seda kasutati nagu teisigi kohalikke taimi.

Rinnavalu vasta um hä̈̈ kolmõkõrralise roho; keedä häste är ja panõ tsükrut mano ja sõs juu. Ka umma muu tii hä̈̈: maasikvarrõtii, vabõrnatii. Vabõrnavarrõ lõigutas lahki piuta lühkasis jupõs, pandas sõs vii sisse - kolmõ toobi vii sisse panõ hä̈̈ käpatäüs. Aja sõs kiimä, keedä häste är, nõrista sõs vesi läbi harva närdso vällä, nii et varrõ perrä jääse. Viile panõ sõs tsükrut mano ja juu häste kuumalt, nii et iho häste higidses lätt. Mine sõs sängü kaska sisse ja higidse sääl õigõ kaua ja sõs aigupitte jaahuda hinnäst, äkki vällä tulla ei tohi. Niisama hää um kah maasiklehetii. Uppinhainatii um kah väega hää, tuud võit õkva peris tii iist juvva, panõ häste tsükrut mano (H I 10, 195 (1) < Kanepi khk, Krootuse k - Gustav Loodus (1896)).

Niisiis on kummeli ja arnika kirjandusliku ja pärimusliku esindatuse vahekord risti vastupidine: arnikat, mida on kirjanduses ja ajakirjanduses nimetatud vaid vilksamisi ja sedagi ajaliselt hilisemates väljaannetes, kajastatakse pärimuses põhjalikumalt ja kindlate viidetega kohalikele taimedele, samas kui kummelit, mida on kirjanduses ja ajakirjanduses ohtralt propageeritud, leidub varasemas pärimuses oluliselt vähem. Hilisemate tekstide osas võib esialgu teha vaid ligikaudset statistikat, sest eesti rahvameditsiini ravimtaimeandmebaas HERBA on alles valmimisjärgus.

Kummelit kasutati HERBA põhjal saadud esialgsete andmete kohaselt kokku 59 näidustuse puhul, kusjuures kõige enam nimetatakse hambahaigusi (18 teksti), sellele järgneb köha (14 teksti), odraiva ja kõrvahaigused (kumbagi 13 teksti), külmetus (12 teksti), silmahaigused (11 teksti) ja palavik (10 teksti). Harvem on nimetatud kõhuhaigusi, krampe, nohu, põletik$\mathrm{ku}$, roosi, kasvajaid, südamehaigusi ja paiset (2-4 teksti). Ülejäänud haiguste ravist kummeliga on vaid üks teade.

Enamik 20. sajandi tekstidest on suuremal või vähemal määral mõjutatud kummeli olulisest kohast akadeemilise meditsiini ravimipagasis, nagu näiteks:

Kui hambajuure all oli põletik, siis hoiti kanget kummeliteed suus. Leige teevesi hoiti suus, seda hiljem alla ei neelatud, vaid sülitati suust välja ja võeti uus suutäis. Lahjemat teevett joodi palavikuliste haiguste puhul. 
Ja üldse jõid seda ka täiesti terved inimesed söögi ajal (RKM II 355, 446/ 7 (109) < Põltsamaa khk - Helle Kull (1981)).

Arnika kasutusulatus on HERBA põhjal oluliselt väiksem, kokku 25 näidustust. Kõige massilisemalt esindatud on venitus (27 teksti), sellele järgneb kõhuvalu (5 teksti) ja ravi kindla diagnoosi korral (3 teksti). Kahel korral on nimetatud jooksvat, külmetust ja seest haigust, mille tunnused sarnanevad venitusega. Ülejäänud näidustusi on nimetatud vaid ühes tekstis.

Huvitav on täheldada, et hilisemad tekstid arnika kohta ei anna mingit vihjet, et tegu võiks olla võõrast päritolu taimega ning on võrreldes kummelit käsitlevate tekstidega lakoonilisemad:

Arnikatee on siis jälle hea, kui sa oled ennast ära venitanud rinde alt (RKM II 14, 43 (86) < Jõhvi khk - Liis Pedajas (1947)).

\section{Kummeli $^{11}$ ja arnika etnofarmakoloogia}

Rahvameditsiinis ei tehtud olulist vahet tee- ja lõhnava kummeli vahel, samas kui toimeainete tasandil on vahe oluline. Teekummel (Matricaria recutita, syn Matricaria chamomilla, Chamomilla recutita) sisaldab sinist eeterlikku õli (hamasuleeni), flavonoidglükosiide, C-vitamiini, mõruaineid, rasvõli, lima jm. Tänapäeval kasutatakse teekummeli õisikuid krooniliste gastriitide, mao- ja kaksteistsõrmiksoole haavandite ning maksa- ja sapiteede põletiku ravis, ka maospasmide ja gaaside vastu. Hamasuleen on kasutusel astma, reuma, ekseemide jt haiguste ravis. On täheldatud kummeli head mõju valulike menstruatsioonide korral, ka emakaverejooksu puhul. Välispidiselt kuristatakse kummeliga kurku, pannakse kompresse raskesti paranevatele haavadele, paisetele, põletikulistele silmalaugudele, valutavale hambale jm. Lõhnava kummeli (Chamomilla suaveolens, syn Matricaria suaveolens ja Matricaria matricaroides) õisikud on tänapäeval kasutusel teekummeli asendajana. Siiski on selle taime põletikuvastane toime teekummeli omast mõnevõrra erinev, sest lõhnava kummeli eeterlik õli ei sisalda matritsiini, millest eeterliku õli destilleerimisel tekib hamasuleeni; ka sisalduvad selles osalt teistsugused flavonoidid (Tammeorg \& Kook \& Vilbaste 1972: 76-80, Sokolov 2000: 240-243, Raal 2003: 65-69, Raal \& Arak 2006: 172-175).

Eesti arnikate prototüübi Arnica montana õitest valmistatud preparaatidel on väikestes annustes kesknärvisüsteemi toniseeriv, suuremates annustes aga sedatiivne, krampidevastane toime. Samas kutsuvad nad esile sapi- 
sekretsiooni ja suurendavad emaka kontraktsioone (Sokolov 2000: 331-333). On teada, et arnikanimeline rohi oli Saksamaal tuntud mõjusa ravivahendina (Vilbaste 1993: 64). Olulisimaks arnika kasutamise viisiks on venituse ravi, arnika kasutamist sel eesmärgil soovitas O. A. Jannau juba 1857. aastal. See annab alust kahelda selle toime seostumises kindla taimega, pigem näib tegemist olevat nime kaudu tekkiva platseeboefektiga. ${ }^{2}$

Vaadeldes arnika kohalikke teisikuid lähemalt, ei ole pilt enam nii ühene. G. Vilbaste (1993) järgi kuulusid arnikate hulka kuus korvõieliste sugukonda kuuluvat liiki. Kaks seanupu perekonna (Leontodon sp) liiki - sügisene seanupp (Leontodon autumnalis) ja kare seanupp (Leontodon hispidus) - olid rahvameditsiinis eristamatud. Veel oli arnika nimetus üldlevinud sellistel taimedel nagu harilik karutubakas (Pilosella officinarum), liiv-koeratubakas (Crepis tectorum) ja harilik kuldvits (Solidago virgaurea). Ka võib selle arvestatavaks teisikuks pidada pajuvaaki (Inula salicina). Kui esimesed viis nimetatud liiki on mägiarnikaga väliselt kogu taime ulatuses sarnased, siis harilik kuldvits sarnaneb vaid õite värvuse poolest. Teiste arnikaks peetud taimede kohta on G. Vilbaste andmebaasis vaid üksikuid teateid. Huvitav on märkida, et G. Vilbaste (1993: 366) järgi nimetab kõigest üks kirjalik allikas arnikaks kohalikku taime - lihtnaistepuna (Jaanau 1870). Kõigis teistes 19. sajandi lõpul ja 20. sajandi alguses ilmunud taimenimetusi puudutavates raamatutes on erinevate arnika-tüve modifikatsioonide all mõelnud mägiarnikat (Arnica montana). ${ }^{13}$ Arnika nime kannab muude taimede seas ka eespool analüüsitud kummel, mille kasutamine põletikuliste protsesside puhul on farmakoloogiliselt igati põhjendatud. G. Vilbaste on arnika nime kasutamist lõhnava kummeli puhul tuvastanud vaid Saaremaal (Vilbaste 1993: 420).

Sügisene seanupp on Eestis levinud taim, mis kasvab niitudel, mererannas ja jäätmaadel. Ka kare seanupp on tavaline taim, kuid eelistab lubjarikkaid kuivi puisniite, niite ja metsaservi (Krall \& Kukk \& Kull et al. 1999: 289,

Foto 4. Sügisene seanupp. Foto Renata Sõukand 2006 .

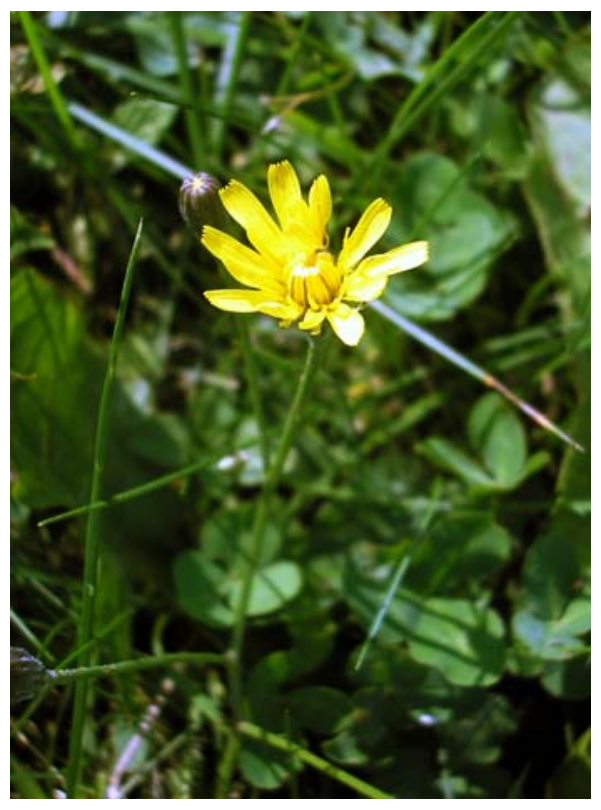


Kukk \& Kull 2005: 89-90). Kumbki seanupp ei ole tänapäeva meditsiinis rakendust leidnud.

Teiseks sagedamini arnikaks nimetatud taimeliigiks on harilik karutubakas (Pilosella officinarum) (G. Vilbaste järgi karvane hunditubakas Hieracium pilosella), mis on Eestis sama levinud kui sügisene seanupp, kasvades kuivades valgusrikastes kohtades (Krall \& Kukk \& Kull et al. 1999: 308, Kukk \& Kull 2005: 98). Harilik karutubakas puudub enamikus ravimtaimeraamatutes, kuid on Dailonis Pakalnsi (2002: 208) andmetel olnud kasutusel loputusvahendina ärrituse vähendamiseks, kootava, analeptilise, turseid vähendava, antibiootilise, antiastmaatilise ja köhavastase vahendina. Ka on seda kasutatud kõhulahtisuse raviks. Kahjuks ei ole D. Pakalns lisanud toimete kirjeldustele allikaid, seepärast on raske tuvastada seost farmakoloogilise toimega. Hoopis tõhusam tõestus on ATC klassifikatsioon (The Anatomical Therapeutic Chemical classification system), mille järgi kuulub karvane hunditubakas diureetiliste, antiastmaatiliste ja köhalahtistavate vahendite hulka (ATC 2002). Ka ladinakeelse nime laiend officinarum viitab kasutamisele apteegis - seega ammutuntud ravimtaimele.

Kolmandaks sagedamini arnikaks peetud taimeliigiks on liiv-koeratubakas (Crepis tectorum), mis on samuti tavaline, liivasel pinnasel, lodudel, teeservadel ja kuivadel nõlvadel kasvav taim (Krall \& Kukk \& Kull et al. 1999: 304). Samas puuduvad andmed sellenimelise taime kohta isegi D. Pakalnsil. Ka ATC klassifikatsioonis see taim puudub.

Harilik kuldvits (Solidago virgaurea) on samuti kohalik taim, mis kasvab Eestis sageli kuivadel niitudel, võsastikes, metsades ja raiesmikel (Krall

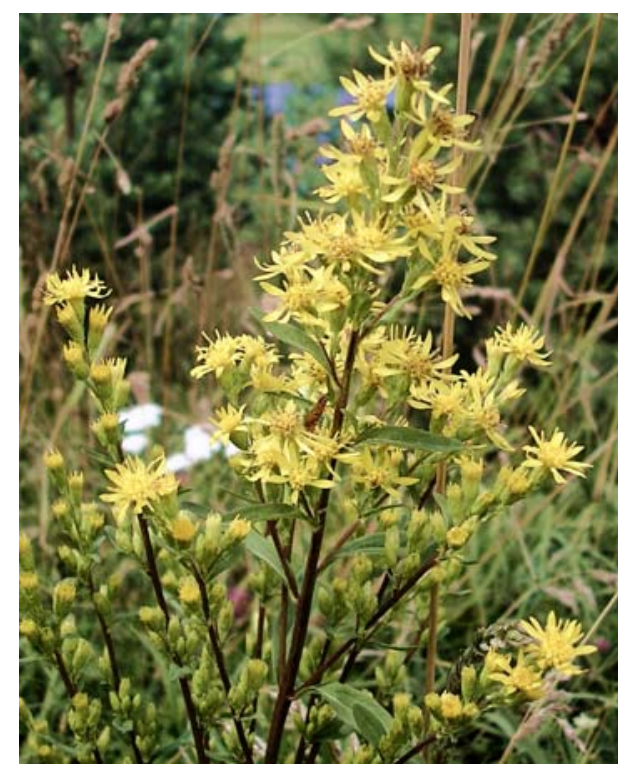
\& Kukk \& Kull et al. 1999: 270, Kukk \& Kull 2005: 105). ATC (2002) klassifikatsiooni järgi kuulub hariliku kuldvitsa ürt taimsete antiseptiliste ja infektsioonivastaste vahendite hulka, mida kasutatakse kuseteede probleemide puhul. D. Pakalnsi (2002: 348) järgi on harilikul kuldvitsal täheldatud nii ärritust vähendavat, kootavat ja toonust tõstvat, oksendamisvastast, vett väljutavat, köha ja astmavastast kui ka kõhulahtisust ja ekseemi vähendavat toimet jne.

Foto 5. Harilik kuldvits. Foto Renata Sõukand 2006. 
Pajuvaak (Inula salicina) kasvab Eestis paiguti, olles tavaline Lääne-Eesti niitudel, metsaservadel ja lodudel (Krall \& Kukk \& Kull et al. 1999: 274, Kukk \& Kull 2005: 87). Seegi taim ei kuulu ametlike ravimtaimede hulka. Küll on aga laialt tuntud ravimtaimena sama perekonna teine liik - aedvaak (Inula helenium). Seda taime on algselt kasvatatud kultuurtaimena, kuid see on hiljem metsistunud ja kasvab Eestis hajusalt (Kukk \& Kull 2005: 87). Ilmselt on pajuvaagis nähtud ka aedvaagi kohalikku, väikesemõõtmelist teisikut. ${ }^{14} \mathrm{Hu}-$ vitav on täheldada, et aedvaagi kasutamine erinevate rahvaste meditsiinis on D. Pakalnsi (2002: 210) andmetel kohati väga sarnane kuldvitsa ja hariliku karutubaka kasutamisele.

Kahel arnika teisikul kuuest on leitud bioloogiline aktiivsus. On see juhuslik? Oluline on märkida, neid kaht kasutatakse haiguste vastu, mis teatud mõttes on samastatavad HERBAs esindatud näidustustega: näiteks venitus klassifitseerub tinglikult ka diureetiliste vahenditega ravitavate hädade alla (kui tegemist on näiteks põiepõletikuga) ja antiastmaatiline toime on kaudselt seostatav külmetusega. Võib oletada, et pajuvaak kui Inula perekonda kuuluv liik võib sisaldada aedvaagiga sarnaseid keemilisi ühendeid. Nende sisaldus ja toime vajab aga põhjalikumat fütokeemilist ja farmakoloogilist uurimist. Asjaolu, et teised taimed ei kuulu ametlike ravimtaimede nimistusse, võib viidata eeskätt nende vähesele uuritusele, sest vaid $15 \%$ katteseemnetaimedest on suuremal või vähemal määral uuritud (Farnsworth \& Soejarto 1992: 38-39).

\section{Nimi muutub “omaks" ja "oma” muutub nimeks}

Soome folkloristi Ilmari Mannineni andmetel on eesti rahvameditsiini üks olulisemaid alustalasid tõdemus, et ravim peab pärinema sealt, kust haiguski (Manninen 1925: 455). Selle põhjal võib eeldada, et ravivahendit otsiti eelkõige kohalikust loodusest. Kuid teisalt on ravimi võõrapärasus oluliseks ravimi kasutuselevõtu teguriks: just "võõraks" olemine annab ravimile lisaväärtuse, erilise jõu, mis aitab haigusest võitu saada (vt ka Sõukand 2005a: 73). Meditsiiniajaloolane Heino Gustavson tõdeb oma raamatus Tallinna vanadest apteekidest (1972: 18): On ju ikka nii olnud, et võõrapärane meelitab ja sellele osutatakse sageli teenimatut tähelepanu.

Ka kultuuris laiemalt on täheldatav sama vastuolu. Analüüsides "oma" ja "võõra" suhteid vene kultuuriruumis eelmistel sajanditel, on märkinud Tartu-Moskva koolkonna tunnustatuim semiootik Juri Lotman:

[---] ühelt poolt on "võõras" sissetungija, teise maailma juurde kuuluv, meil ajutiselt viibiv. Teisalt on "oma-võõras" ka šamaan, teadja, kes kuu- 
lub korraga "oma" ja "võõra" maailma. Esimesel juhul on "võ̃oras" vaenu ja kaitse objekt, teisel juhul hirmu ja austuse objekt (Lotman 2002: 222).

Sellest tulenevalt võib oletada, et saavutamaks olulist kohta rahvameditsiinis, peab taim muutuma "oma-võõraks", säilitades osalt võõrapärasuse, kuid omandades samas "omale" iseloomulikke jooni. Meie näidistaimede omakssaamine on toimunud kahel viisil.

Etnobotaanik Brent Berlin tõdeb, et mida olulisem taim, seda lihtsam sõna, mida nimena kasutatakse. Kõrvutades erinevatesse keelerühmadesse kuuluvate hõimude taimenimesid, leidis ta, et kultiveeritud taimedest on $80 \%-1$ lingvistiliselt analüüsimatu nimi.

Liigi lihtsa, läbipaistmatu sõnaga nimetamise tõenäosus kasvab, kui kasvab selle tähtsus kultuuris (Berlin 1992: 256).

Seega võib oletada, et nime läbipaistvuse (opaque ${ }^{15}$ ) põhjal saab määrata taime olulisust kultuuris (vrd ka Sõukand 2004). Kas see väide kehtib ka võõra päritoluga nime kohta? Kui näiteks nimetus kummel, mis on saksakeelse Kamille teisendus, on tänapäeva uurijale arusaadav, siis vaevalt oli see seda 18.-19. sajandi eesti talupojale, kes taime nõnda nimetama hakkas. Kuid mis tähtsusest kultuuris saame rääkida taime puhul, mis on Eesti pinnal kasvanud napilt kaks sajandit? G. Vilbaste leiab, et võõrapärased nimevariandid kinnistusid just seepärast kiiresti ja kergesti, et rahvapärane nimetus on halvamaiguline (kanaperse), mida ei taheta viisakas kõnelemises meeleldi tarvitada (Vilbaste 1993: 422). Võõrapärane nimi on muutunud "omaks" väikese muganduse abil, säilitades võõraga kõlasarnasuse. Seega, kui taim on võõras ja võorrapärase nimega, on kõige parem viis taime "omaksvõtuks" võõrapärase nime mugandamine.

G. Vilbaste kirjeldab ühte paljudest eesti taimenimede kujunemise viisidest järgmiselt:

Taimenimesid tõlgiti peamiselt möödunud sajandil; saksa kultuuri ja keele mõjul on osa taimenimesid tõlgitud sõna-sõnalt saksa keelest. Pealegi olid möödunud sajandi algupoolel ja varemgi pastorite ja osalt ka mõisaomanike prouad oma ümbruse inimestele, vähemalt mõisateenijatele, arstlikeks nõuandjateks. Nad olid oma teadmised omandanud saksakeelsetest rohuraamatutest. Et abivajajatel jääks taime nimi paremini meelde, tõlgiti see, või öeldi ka saksakeelne nimi, mis moonutatult kasutusele tuli (Vilbaste 1993: 66).

Nimi on sõna, mida seostatakse taimega. Sõna aga on kas oma või võõras. 
Ma elan võõraste sõnade maailmas. Kogu mu elu on selles maailmas sihi otsimine. [---] Võõras sõna annab inimesele erilise ülesande selle sõna mõistmiseks (selline ülesanne puudub oma sõna puhul) (Mihhail Bahtin, Estetika slovestnogo tvortsestva, Moskva 1979: 347-348 - viidatud Torop 1995: 140 järgi).

Võõrale sõnale otsitakse uusi tähendusi või muudetakse seda vastavalt vajadusele, võõras sõna omandab oma koha läbi teisenduse.

Kummeli puhul on täheldatav ka teine "omaks" saamise võimalus: nimelt on nime kummel modifikatsioone hakanud kandma harilik kesalill (Matricaria perforata, syn Tripleurospermum inodorum) - ilmselt sellepärast, et teekummeli õisikud on väliselt väga sarnased kesalille õisikutega, kuigi kummeli õisikupõhi on õones, kesalillel aga täidetud valkja säsiga. Kuid teateid sellisest nimekasutusest on üksikuid (Vilbaste 1993: 633), liiatigi võib oletada, et need on tingitud sellest, et A. W. Hupel nimetas 1818. aastal kesalille kanaperseks - nimetus, mida kummelilegi kirjanduses külge püüti pookida (Vilbaste 1993: 633).

J. Lotmani arvates jaguneb suhtlusprotsess kahe võora kultuuri vahel järgmisteks etappideks: esialgu esineb ühepoolne informatsiooni edasikandmine, kusjuures vastuvõtja salvestab ka arusaamatuid tekste. Järgnevalt "võõrkeel" omandatakse ja seda hakatakse vabalt kasutama, omandatakse ka võõraste tekstide kujunemise reeglid ja nende põhjal luuakse uued reeglid.

Siis saabub kriitiline hetk: võorras traditsioon transformeerub vastavalt vastuvõtja algupärasele semiootilisele alusele. Võõras muutub omaks ja minetab tihti oma esialgse kuju (Lotman 2002: 48).

Arnika on sellise omapärase "võõra" "omaks" muutumise musternäidis.

\section{Kokkuvõte}

Kahe näidistaime põhjal ei saa küll teha põhjapanevaid järeldusi "oma" ja "võõra" suhetest rahvameditsiini taimravis, kuid võib joonistada välja mõningaid tendentse. Mõlemad vaadeldavad taimed on ajapikku muutunud "omaks", säilitades ka algse "võõrast" hõngust tekkinud erilise, lisajõudu lubava tähenduse. Lisateguriks võib siinjuures pidada nende nimede taga peituvate liikide (eriti kummeli) reaalset farmakoloogilist toimet. Taimede omakssaamise teed on aga erinevad. Kummel, säilitades võõrapärase nime ja seose kindla taimeperekonnaga, on end kehtestanud loodusruumis. Arnika aga laenas oma nime 
välimuselt sarnastele ja/või juba varem rahvameditsiinis kasutusel olevatele taimeliikidele, levides nii hoopis kultuuriruumis. Jakob Hurda kogus sisalduvate ravimtaime tekstide põhjal võib sealjuures väita, et ajaline eelis oli kultuuriruumi levinud taimel (arnikal), sest selle teisikud olid juba olemas ja tõenäoliselt ka kasutatavad ühe või teise haiguse puhul, seega piisas vaid nimevahetusest. Kummel aga pidi ootama ulatuslikumat loodusesse levikut, muutudes alles seejärel laialt kasutatavaks ja saavutades lõpuks isegi suurema populaarsuse kui arnika.

\section{Kommentaarid}

1 Käesolev artikkel on valminud riikliku programmi "Eesti keel ja rahvuslik mälu" projekti HERBA raames. Autor tänab Mare Kõivat ja kahte anonüümset retsensenti kommentaaride ja nõuannete eest, mis aitasid artiklit paremaks teha, ning Rein Saukast abi eest Jakob Hurda korrespondentide bibliograafiliste andmete otsimisel. Samuti tänan Stella Martsood, kes lubas kasutada enda sisestatud kalendritekste, ning Salle Kajakut, Eva-Kait Kärblast ja Mairit Oleskit abi eest raamatutekstide sisestamisel ja kontrollimisel. Varasem (oluliselt kärbitud) versioon artiklist ilmus elektroonilises ajakirjas Hortus Semioticus (http://www.ut.ee/ hortussemioticus/).

2 18. ja 19. sajandi näitetekstid on esitatud vanas kirjaviisis.

3 Ei polle kuulnud neist ühtegi ütlemist, egga mõista ma siis muud nimmetada kui agga ni paljo: vahhest lasseb kanna omma hänna sulgi tuult laiale ajada, ja näitavad temma sulled siis nenda sammoti ratta visi välja, kui selle lille õied; küllap sest se rohho nimmi kanna persed vetud ja sadud (Rosenplänteri käsikiri, lahtised lehed (tsiteeritud Vilbaste 1993: 633 järgi). Laiend "saksa" viitab taime võõramaisele päritolule.

4 Põhjalikult on humaanravimite kajastamist kalendrites analüüsinud Stella Martsoo (2007).

5 August Heinrich Schmidt (1760-1861) - tõlkija, keeleuurija ning Valjala koguduse opetaja ja Saaremaa kirikukohtu vanem.

${ }^{6}$ Raamatut anti aastatel 1857-1894 välja kuus trükki, kokku 12500 eksemplari, kusjuures 1870. aastal anti välja parandatud trükk. Selle raamatu tsiteerimisel on kasutatud neljandat trükki.

7 Raamat ilmus kolmes trükis, kokku 11000 eksemplari; originaali pealkiri ja tõlkija ei ole teada.

${ }^{8}$ Originaal Meine Wasserkur ilmus aastal 1886. Raamatust ilmus vaid üks trükk (3000 eksemplari).

9 Venitus on [haigestumise] teine suurem põhjuste grupp peale külmetust. Kaevati, et inimene oli ennast "ära tõstnud", "ära venitanud", "tööga ära tapnud", "südame sooned ära venitanud", "naba kohalt ära nihkunud". Nende kaebuste all tuleb küll mitmesuguse päritoluga kroonilisi haigusi mõista, nagu mao-sooletrakti katarr, südamelihaste, ka teiste lihaste haigusi (Lüüs 1959: 185). Seest haiguseks võidi nimetada suvalist valuaistingut või ebamugavustunnet, mis seostus siseorganitega (peamiselt kõhu piirkonnas). 
${ }^{10}$ Viimase puhul saab Gustav Vilbaste Eesti taimenimetuste (1993) alusel valida mitme taimeliigi vahel (nt pajuvaak, harilik näär, kollane võhumõõk, kollane ängelhein jne).

${ }^{11}$ Kummeli etnofarmakoloogiat on põhjalikult analüüsinud Ain Raal ja Elmar Arak (2006: 158-150), seepärast peatutakse käesolevas töös sellel vaid põgusalt.

12 Platseeboks nimetatakse ravimit, mis kutsub esile paranemise, omamata reaalset, konkreetsele haigusele mõjuvat bioaktiivsust (täpsemalt platseebo kui fenomeni kohta vt Sõukand 2005b).

${ }^{13}$ Eelnevast kirjanduse analüüsist selgus siiski, et lihtnaistepuna kirjeldus esines arnika nime all küll ka tõlkekirjanduses (Kneipp 1895), kuid sellesse teosesse oli tõlkija teinud hulga täiendusi.

${ }^{14}$ Aedvaagi kajastamist kuni 1900. aastani ilmunud aimekirjanduses on uurinud Raivo Kalle (2007: XXX).

${ }^{15}$ Bent Berlin kasutab sellist väljendit tähistamaks lingvistiliselt analüüsimatut sõna.

\section{Arhiiviallikad}

H = Jakob Hurda rahvaluulekogu, 1860-1906

EKM = Eesti Teaduste Akadeemia Fr. R. Kreutzwaldi nim. (Riikliku) Kirjandusmuuseumi (nüüd Eesti Kirjandusmuuseumi) rahvaluule osakonna rahvaluulekogu, peamiselt alates 1945. aastast

\section{Kirjandus}

ATC 2002. Draft herbal ATC index. Uppsala: Uppsala Monitoring Centre.

Berlin, Brent 1992. Ethnobiological Classification: Principles of Categorization of Plants and Animals in Traditional Societies. Princenton (New Yersey): Princenton University Press.

EMRK 1803: Eesti-Ma Rahva Kalender, ehk Täht-Ramat 1804 Aasta peäle, pärrast meie Issanda Jesusse Kristusse Sündimist. Tallinn: Minuth.

ERK 1856 = Eesti rahva Kalender se 1857 aasta peale pärrast J. Kristusse sündimist: Se Kalender on Öigeussu tunnistusse rahwa tarbeks sisseseädetud. Riia: Müller.

ERK 1857 = Eesti rahva Kalender se 1858 aasta peale pärrast J. Kristusse sündimist: Se Kalender on Öigeussu tunnistusse rahwa tarbeks sisseseädetud. Riia: Hartung. ERKK 1886 = Eesti-rahva Kasuline Kalender 1887. aasta peale. Tartu: H. Laakmann. Gustavson, Heino 1972. Tallinna vanadest apteekidest kuni 1917. a. Tallinn: Valgus.

Farnsworth, Norman R. \& Soejarto, Djaja D. 1992. Global Importance of Medicinal Plants. Akerle, Olayiwola \& Heywood, Vernon (= Hilton, Vernon) \& Synge, Hugh (toim). The Conservation of Medicinal Plants: Proceedings of an International Consultation, 21-27 March 1988, Held at Chiang Mai, Thailand. Cambridge \& New York: Cambridge University Press, lk 25-51. 
Hagemeister, Nicolaus von 1790. Lühhikene öpetus maarahvale, mis visi nendega peab ümberkäma, kes vees uppunud ja muu villetsusse sisse sanud, ehk äkkitselt surnud, et nemad ello jälle voiksid sada. Tallinn: Iwerseni in Wermer.

HERBA. Eesti rahvameditsiini ravimtaimede andmebaas (http://www.folklore.ee/herba -29. detsember 2006).

Hupel, August Wilhelm 1777. Topographische Nachrichten von Lief- und Ehstland 2. Riga: Johann Friedrich Hartknoch (vt ka http://www.utlib.ee/ekollekt/buecher/ Hupel,TopogrNachricht.pdf - 12. jaanuar 2007).

Jaanus, Johannes 1893. Rahva tohter: Arstlikud õpetused, kudas inimesed endid haiguste eest võiksivad hoida ja tõbesid parandada. Vändra: Mats Tõnisson.

Jannau, Otto August von 1857. Ma-rahva Koddo-Arst, ehk, lühhikenne juhhataja, kuida iggaüks mõistlik innimenne ommas maias ja perres, kui kegi haigeks saab, agga arsti ep olle sada, vöib aidata. Tartu: H. Laakmann.

Jannau, Otto August von 1870. Maa-rahva kodu-Arst ehk lühikene juhataja, kuida igaüks mõistlik inimene oma maeas ja peres, kui keegi haigeks saab, aga arst ep olle saada, võib aidata. 4., parand tr. Tartu: H. Laakmann.

Kalle, Raivo 2007. Naturaliseerunud ravimtaimed etnobotaanika vaatenurgast. Hariliku katkujuure, hariliku siguri, aedvaagi, aed-mädarõika, hariliku seebilille ja lõhnava kannikese näitel. Mäetagused: Hüperajakiri 36, lk 105-128 (vt ka http:// www.folklore.ee/tagused/nr36/kalle.pdf).

Kneipp, Sebastian 1894. Meine Wasserkur. 49. trükk (http://www.med-serv.de/medizinbuch-wasserkur-1-1-1.html - 18. jaanuar 2007).

Kneipp, Sebastian 1895. Uus tohter: Õpetused, kudas inimesed igasugu haiguseid aurutamistega, vee-vannitustega, peale valamistega, märja-mähitustega j.n.e. kui ka oma korjatud rohtudega arstida võivad. Vändra: Mats Tõnisson.

Krall, Heljo \& Kukk, Toomas \& Kull, Tiiu \& Kuusk, Vilma \& Leht, Malle \& Oja, Tatjana \& Reier, Ülle \& Sepp, Silvia \& Zingel, Hanno \& Tuulik, Taavi 1999. Eesti taimede määraja. Leht, Malle (toim). Tartu: Eesti Loodusfoto.

Kukk, Toomas 1999. Eesti taimestik. Eesti looduse mitmekesisus. Tallinn: Teaduste Akadeemia Kirjastus.

Kukk, Toomas \& Kull, Tiiu (toim) 2005. Eesti taimede levikuatlas = Atlas of the Estonian Flora. Tartu: Eesti Maaülikool.

Lotman 2002 = Лотман, Юрий. Нстория и типоловия русской культуры. Санкт-Петербург: Искусство-СПБ.

Luce, Johann Wilhelm Ludwig von 1816 Terwisse Katekismusse Ramat: Se on nisuggune ramat, kus sees küssides ja kostes öppetakse, kuida innimenne woib ja peab omma ihho terwist hoidma ja selle pärrast hoolt kandma = Gesundheits-Catechismus für das ehstnische Landvolk... Tallinn: [s.n.].

Luce Johann Wilhelm Ludwig, von 1823. Topographische Nachrichten von der Insel Oesel, in medicinischer und ökonomischer Hinsicht = Prodorms Florae osiliensis: Topographische Nachrichten von den auf der Insel Oesel vachsenden Pflanzen, nebst Bemerkung ihres Nutzes in der Medicin, Oekonomie und Technik. Riga: W. F. Häcker. 
Lüüs, Aadu 1959. Rahvahaigused ja rahva ravimisviisid Võrumaal 19. sajandi viimsel veerandil I. Mana 3, lk 184-187.

Maja tohter: Juhatus, kudas arsti-abi puudusel igasugu haigusi ise võib kergitada ja parandada. 1891. Tallinn: K. Laurmann.

Manninen, Ilmari 1925. Üldjooni meie rahvameditsiinist. Eesti Kirjandus 11, lk 453459.

Martsoo, Stella 2007. Ravimid 18. ja 19. sajandi eestikeelses kalendrikirjanduses. Mäetagused: Hüperajakiri 36, lk 7-34 (vt ka http://www.folklore.ee/tagused/nr36/ martsoo.pdf).

Pakalns, Dailonis 2002. Lexicon plantarum medicinalium polyglotum = Ārstniecības augu vārdnīca = Wörterbuch der Heilkräuter = Dictionary of Herbs. Rīga: Tevans.

PERK 1879 = Otstavel, Jaan (toim). Pärnu Eesti-rahva Kalender ehk Täht-raamat 1880 aasta pääle, pärast Jeesuse Kristuse sündimist. Pärnus: W. Borm.

PK 1879 = Pärnu Kalender ehk Täht-raamat 1880 aasta pääle, pärast Jeesuse Kristuse sündimist. Tartu: G. V. Rosenberg.

Raal, Ain 2003. Taimedes talletuv tervis. Tallinn: Valgus.

Raal, Ain \& Arak, Elmar 2006. Eesti Etnofarmakognoosi elujõust kummeli näitel. Mäetagused: Hüperajakiri 34, lk 149-184 (http://www.folklore.ee/tagused/nr34/kummel.pdf - 28. detsember 2006).

RTR 1886 = Tõnisson, Mats. Rahva Täht-raamat (Adressi kalender) 1887 aasta jaoks, millel 365 päeva on. Vändra: M. Tõnisson.

SL 1898 = Sirvilauad 1899: Eesti rahva Tähtraamat 1899 aasta jaoks. Jurjev (= Tartu): Eesti Üliõpilaste Selts.

Sokolov 2000 = Соколов, Сергей Я. Фитотерапия и фитофарлакология: Руководство для врачей. Москва: Медицинское информационное агентство.

Sõukand, Renata 2004. “Jooksvarohud” Eesti rahvameditsiinis. Akadeemia 11, lk 24752493.

Sõukand, Renata 2005a. Loodus eesti rahvameditsiinis. Maran, Timo \& Tüür, Kadri (koost \& toim). Eesti looduskultuur. Tartu: Eesti Kultuuriloo ja Folkloristika Keskus \& Eesti Kirjandusmuuseum, lk 55-79.

Sõukand, Renata 2005b. Platseebo - kelle jaoks vale? Öpik, Maarja et al. (toim). Vale teooria. Schola Biotheoretica 31. Tartu: Eesti Looduseuurijate Selts, lk 56-61.

SWHKK $1895=$ S. W. Haynbergi värvi- ja vürtsikaupluse Kalender 1896 aasta tarvis. Valga: S. W. Haynberg.

Tammeorg, Johannes \& Kook, Oskar \& Vilbaste, Gustav 1972. Eesti NSV ravimtaimed. 2., ümbertööt. tr. Tallinn: Valgus.

Torop 1995 = Тороп, Пеэтер. Тотальный перевод. Тарту: Tartu Ülikooli Kirjastus.

Vilbaste, Gustav 1993. Eesti taimenimetused = Nomina vernacula plantarum Estoniae . Eesti Teaduste Akadeemia Emakeele Seltsi toimetised 20p Tallinn: ETA Emakeele Selts (http://www.loodus.ee/vilbaste/ - 12. jaanuar 2006). 
Wallner, Rudolf (= Vallner, Rudolf) 1929. Eesti rahvarohtude sõnastik: Käsiraamat apteekritele ja arstidele. Tallinn: R. Wallner.

Wilde, Peter Ernst 1771. Arsti raamat nende juhhatamisseks kes tahtvad többed ärraarvada ning parrandada. Hupel, August Wilhelm (tõlk). Põltsamaa: W. J. v. Lauw.

Wilde, Peter Ernst. 1976 [1766-1767]. Lühhike öppetus mis sees monned head rohhud täeda antakse, ni hästi innimeste kui ka veiste haigusse ning viggaduste vasto; et se kellel tarvis on, voib moista, kuida temma peab nou otsima ning mis tulleb tähhele panna igga haiguse jures... Hupel, August Wilhelm (tõlk). Faksiimiletrükk. Tallinn: Valgus.

Vietinghoff-Scheel, Burchard Christoph von 1807. Oppetus kuitao ma-rahvas henda kötto-többe eest peap hoidma ehk kui ta selle kimpu sisse om johtnu, temmast pea jälle voip avvitetus sada: Tallomeeste häes üleskirjotu. Rühl, Otto Friedrich Paul von (tõlk läti keeled) \& Lenz, Friedrich David (tõlk eesti k). Tartu: M. G. Grenzius.

\section{Summary}

\section{How foreign becomes own: two plants in Estonian folk medicine}

\section{Renata Sõukand}

Key words: arnica, Estonian folk medicine, camomile, foreign and own, herbal medicine

In order to become relevant in a given culture, the imported phenomena (e.g. medicinal plants) have to be integrated into own, while also remaining 'foreign' in some respect (which, in the case of medicinal plants, gives additional potency to their healing power). The paper takes as examples two imported species of herbs introduced into Estonian ethnomedicine before the 19th century: arnica and camomile. Camomile was already described as a medicinal plant in the first medicinal magazine in Estonian (in 1776), whereas arnica emerged in the popular medicinal literature in the middle of the 19th century. In the folklore collection of Jakob Hurt arnica seems to be more popular than camomile and is described there as a local plant. Indeed, according to the information of Gustav Vilbaste, the first Estonian ethnobotanist, there where altogether 19 local plants known by the phytonym. Arnica montana (the prototype of arnica name) did not get acclimatized in the Estonian climate and thus became 'own' by extending its name to locally grown plants, a process that could be called cultural acclimatization; Matricaria sp. acclimatized here, shifted from the cultural sphere to natural and from there into the medical use of the common people. In the more recent tradition, camomile exceeded arnica in popularity; this might have been influenced by its popularity in the 20 th-century medical literature. 